\title{
TOWARD A THEORY OF "JUST CAUSE" IN EMPLOYEE DISCIPLINE CASES*
}

\author{
Roger I. AbRAMS** AND DENNIS R. Nolan***
}

\begin{abstract}
Although almost every collective bargaining agreement permits the employer to discipline an employee for "just cause," the concept of just cause is not well understood. Rather than leading to fair and consistent resolutions of disciplinary disputes, the concept, as applied in arbitration proceedings, has led to inconsistent results that fail to serve the interests of either management or labor. This article develops a systematic theory of just cause in employee discipline cases by exploring the fundamental understanding of the employment relationship and the effect of the collective bargaining agreement on the fundamental understanding. It presents a model of just cause, identifying the components of the employee's obligation to provide satisfactory work, management's objectives for imposing discipline, and the union's objective of achieving fairness in discipline administration. By illustrating the application of the theory, the article demonstrates the value of a principled approach to just cause-employers and employees can better shape their day-to-day conduct, and arbitrators can more consistently honor the expectations of the parties.
\end{abstract}

\section{INTRODUCTION}

"Just cause" for discipline is the most important principle of labor relations in the unionized firm. Few things are more significant to employees than limitations on their employer's power to discipline or discharge then. Virtually every collective bargaining agreement contains some such limitations, by far the most common of which is the requirement that there be "just cause" for discipline. ${ }^{1}$ This requirement is so well accepted that often it is found to be implicit in the collective agree-

* Copyright $\odot 1985$ by Roger I. Abrams and Dennis R. Nolan. This article is part of a work in progress, a treatise on labor arbitration to be published by West Publishing Company under the title American Labor Arbitration.

** Professor of Law, Case Western Reserve University School of Law. B.A., 1967, Cornell University; J.D., 1970, Harvard Law School.

*** Professor of Law, University of South Carolina School of Law. A.B., 1967, Georgetown University; J.D., 1970, Harvard Law School; M.A., 1974, University of Wisconsin-Milwaukee.

We are grateful to Professor Hoyt Wheeler of the University of South Carolina College of Business Administration and Professor Calvin Sharpe of Case Western Reserve University School of Law for their helpful comments on a draft of this article.

1. In its survey of major collective bargaining agreements, the Bureau of National Affairs reported in 1983 that $94 \%$ of the agreements revicwed contained a "just cause" or "cause" provision. 2 Collective Bargaining: Negotiations aNd Contracts (BNA) $§ 40: 1$ (1983). 
ment, even when there is no stated limitation on the employer's power to discipline. ${ }^{2}$ However, while the just cause standard is well accepted and is commonly an express part of the agreement, the parties seldom define the term in any detail.

Collective bargaiming agreements typically provide for arbitration of disputes concerning the interpretation or application of the contract. As a result, arbitrators are routinely required to apply tlie just cause standard in order to evaluate the propriety of disciplinary action. Cases involving disciplinary action constitute the largest category of disputes brought to arbitration, accounting for two-fifths of the total. ${ }^{3}$ In light of the importance of the just cause standard to labor and management, and the frequency with which arbitrators must apply it, it is surprising that little lias been written on tlie subject. ${ }^{4}$

Just cause is hardly an obvious concept. When applying it to specific cases, arbitrators tend to define just cause in nebulous terms or to make conclusory statements. For example, "reasonable" discipline is permissible, 5 but "arbitrary," "excessive," or "discriminatory" discipline is not. 6 A penalty that does not "sliock the conscience" of tlie arbitrator is uplreld, 7 but one thrat is not "just" under "all the circumstances" is set aside. ${ }^{8}$ In fact, one arbitrator characterized the term "just cause" as "purposefully ambiguous." Although some arbitrators liave identified various procedural prerequisites for just cause, even they liave failed to

2. Alfred M. Lewis, Inc., 81 Lab. Arb. (BNA) 621, 624 (1983) (Sabo, Arb.); Corn Belt Elec. Coop., 79 Lab. Arb. (BNA) 1045, 1049 (1982) (O’Grady, Arb.); Cameron Iron Works, Inc., 25 Lab. Arb. (BNA) 295, 300-01 (1955) (Boles, Arb.).

3. The Federal Mediation and Conciliation Service reports that approximately $40 \%$ of the cases it administered over the 10 year period 1972-1981 involved discharge or disciplinary matters. 34 Federal Mediation and Conciliation Service ANNual Report $40-41$ (1981).

4. A useful work for the practitioner is James R. Redeker's recent book, DiscIPLINE: PoLICIES AND Procedures (1983). Jean T. McKelvey's chapter on "Discipline and Discharge," in ARbitration IN Practice 88 (A. Zack ed. 1984), also provides insight into the area. Articles on various types of discipline cases have appeared recently in the Arbitration Journal, published by the American Arbitration Association. See, eg., Cramer, Arbitration and Mental Illness: The Issues, the Rationale, and the Remedies, 35 ARB. J., Sept. 1980, at 10; Marmo, Arbitrating Sex Harassment Cases, 35 ARB. J., Mar. 1980, at 35; Wynns, Arbitration Standards in Drug Discharge Cases, 34 ARB. J., June 1979, at 19.

5. See 3 M Co., 80 Lab. Arb. (BNA) 926, 928 (1983) (Gallagher, Arb.); Napoleon Bd. of Educ., 74 Lab. Arb. (BNA) 303, 305 (1980) (Roumell, Arb.); Riley Stoker Corp., 7 Lab. Arb. (BNA) 764, 768 (1947) (Platt, Arb.).

6. See United States Sugar Corp., 82 Lab. Arb. (BNA) 604, 609 (1984) (Hanes, Arb.); Kansas City Area Transp. Auth., 82 Lab. Arb. (BNA) 409, 413 (1984) (Maniscalco, Arb.); Atlantic Richfield Co., 69 Lab. Arb. (BNA) 484, 487 (1977) (Sisk, Arb.).

7. See Monarch Mach. Tool Co., 82 Lab. Arb. (BNA) 880, 883 (1984) (Schedler, Arb.).

8. See City of Kalanazoo, 82 Lab. Arb. (BNA) 138, 140-41 (1983) (Ellmann, Arb.).

9. Municipality of Anchorage, 82 Lab. Arb. (BNA) 256, 263 (1983) (Hauck, Arb.). 
base their proposals on a comprehensive theory of employee discipline. ${ }^{10}$

Leaving the determination of just cause to the discretion of effectively unreviewable arbitrators" leads to inexplicable results. An employee whose comments to a client were only "vulgar" and "offensive," and not "obscene" or "prurient," should not have been discharged, but only suspended without pay for six months. ${ }^{12}$ Discharge was too severe for an employee who, in order to pad his paycheck, intentionally performed unnecessary work, because his act was not "malicious."13 Such decisions fail to serve the interests of either management or labor. They provide neither guidance for future conduct nor persuasive rationales. A systematic model of just cause is thus needed to guide employers and employees in their day-to-day conduct and to assist arbitrators in resolving disciplinary disputes.

This article is a preliminary effort toward the development of a theory of just cause. The article begins by describing the "fundamental understandimg" that forms the basis of every individual hiring. ${ }^{14}$ It then explains how unions ratify and amend this fundamental understanding in collective bargaining agreements, most importantly by adopting the just cause standard for discipline. ${ }^{15}$ The next two sections of the article describe the interests of management and labor in disciplinary disputes and suggest how those interests are reflected in the concept of just cause. ${ }^{16}$ The article then states a theory of just cause that is consistent with the fundamental understanding, the collective bargaining process, and the legitimate interests of both parties. ${ }^{17}$ The final portion of the article illustrates the application of the theory. ${ }^{18}$ An examination of some typical cases demonstrates that most arbitration awards, when properly understood, are consistent with our theory of just cause and reflect the implicit acceptance of that theory by labor arbitrators.

10. See infra note 30 .

11. The Supreme Court severely limited the authority of courts to review labor arbitration awards in United Steelworkers v. Enterprise Wheel \& Car Corp., 363 U.S. 593 (1960). See Nolan \& Abrams, American Labor Arbitration: The Maturing Years, 35 U. FLA. L. Rev. 557, $590-91$ (1983).

12. See City of Rochester, 82 Lab. Arb. (BNA) 217, 220 (1984) (Lawson, Arb.). Cf. City of Sterling Heights, 3 LAB. Rel. ReP. (BNA) (84 Lab. Arb.) 363, 366 (Feb. 13, 1985) (Keefe, Arb.) ("lewd occurrence" and "bacchanal" in the women's bathroom sufficient to support discharge).

13. See Ellwell-Parker Elec. Co., 82 Lab. Arb. (BNA) 327, 335 (1984) (Dworkin, Arb.).

14. See infra notes $19-22$ and accompanying text.

15. See infra notes 23-34 and accompanying text.

16. See infra notes $35-65$ and accompanying text.

17. See infra text accompanying note 66 .

18. See infra notes 67-105 and accompanying text. 


\section{The FUndamental UNDERSTANDing}

When a homeowner hires a neighborhood teenager to mow the lawn, there is little formality in the transaction. The two may discuss wages and hours, but only in a rudimentary way. Few other details are likely to receive even that much attention. When a factory personnel manager hires a machinist, the discussion may last a bit longer, but it is still likely to be limited to basic information about the work required and the benefits offered. Little discussion is needed because all hirings are premised upon a common understanding of the parties' interests. This understanding is fundamental to the very nature of the employment relationship. A potential employer is willing to part with his money only in return for something he values more highly, the time and satisfactory work of the employee. The potential employee will part with his time and work only for something he values more, the money offered by the employer. Each is, to some degree, aware of the other's interests. ${ }^{19}$

This fundamental understanding of the employment relationship can be easily summarized: both parties realize that the employer must pay the agreed wages and benefits and that the employee must do "satisfactory" work. "Satisfactory" work, in this context, has four elements: (1) regular attendance, (2) obedience to reasonable work rules, (3) a reasonable quantity and quality of work, and (4) avoidance of any conduct that would interfere with the einployer's ability to operate the business successfully. ${ }^{20}$ The common phrase, "a fair day's work for a fair day's pay," attempts to capture the essence of this understanding. While the fundamental understanding is so limited as barely to constitute a bargain, it does provide the framework for the employment relationship. ${ }^{21}$

As limited as it is, the fundamental understanding may appear to be unbalanced. The obligations of the employee seem to be more numerous and perhaps more onerous than those of the employer. This perception of unfairness is not always accurate, lowever. As a matter of economics, the employee would not undertake his obligations unless he regarded the wage and benefit level to be fair compensation for lis time and effort.

19. See generally N. Chamberlain, The Union Challenge to Management Control (1948); M. Chandler, Management Rights AND Union INTERests 66-82 (1964); R. Hoxie, Trade Unionism in the United States 284-85 (1917); O.W. Phelps, Discipline and DisCHARGE IN THE UNIONIZED FIRM (1959); Chamberlain, The Philosophy of American Management Toward Labor, in LABOR IN A ChaNGING AMERICA 171, 181-83 (W. Haber ed. 1966); Young, The Question of Managerial Prerogatives, 16 INDuS. \& LAB. REL. REV. 240, 245-46 (1963).

20. See, e.g., North Am. Aluminum Corp., 80 Lab. Arb. (BNA) 1034, 1035 (1983) (Daniel, Arb.) ("The obligation of an employee is not totally connected with the volume or quantity of his work but rather also with his observation of the fair and reasonable standards and conditions of employment."). See generally B. KarSH, DiaRY OF A STRIKE 8-11 (1958).

21. See generally J. Commons, Legal Foundations of CAPITALISM 285-86 (1968). 
Moreover, when the demand for labor exceeds the available supply-a situation that existed throughout this country for much of its history and still exists with regard to certain skills-the employee's obligations will be reduced and his wages increased. ${ }^{22}$

True or false, the belief that the fundamental understanding of the employment relationship is unbalanced is one of the main factors causing employees to unionize. ${ }^{23}$ When a union negotiates a collective bargaining agreement, it does so against the background of this fundamental understanding. Far from repudiating that understanding, collective agreements always ratify it, sometimes implicitly but usually explicitly. This occurs for several reasons. First, unions are composed of individual employees, each of whom understands the nature of the exchange between employer and employee. Second, unionized employees realize that the economic health of the employer, a determinant of their continued employment, depends to some degree on their efficiency. Finally, diligent employees know that "shirkers" simply make work more difficult for other employees.

A collective agreement incorporates the fundamental understandmg, but also provides it with sufficient detail that it properly can be termed a bargain. The result is likely to be more balanced than the fundamental understanding itself. For example, the agreement may carefully define the quantity and type of work required, and it almost certainly will spell out in some detail the benefits employees are to receive.

For the employees, the most important effect of the collective agreement is the correction of what they perceive to be the major flaw of the fundamental understanding - the insecurity of the relationship. $.^{24} \mathrm{Be}-$ cause the fundamental understanding is limited to the exchange of money for work done, either side may terminate the relationship at will. ${ }^{25}$ This usually presents little problem for employers, but for em-

22. See Dunlop, The Task of Contemporary Wage Theory, in THE THEORY OF WAGE DeTERMiNATION 3, 26-27 (J. Dunlop ed. 1957).

23. See Kochan, How American Workers View Labor Unions, 102 MoNTHLy LAB. REv., Apr. 1979, at 23, 25; see also Ashenfelter \& Pencavel, American Trade Union Growth, 1900-1960, 83 Q. J. ECON. 434, 435-39 (1969); Bakke, Why Workers Join Unions, 22 PersonNel 37 (1945); Hammer \& Smith, Work Attitudes as Predictors of Unionization Activity, 63 J. APP. PsYcH. 415 (1978).

24. See generally A. Flanders, MANagement AND UNions 38-47 (1970).

25. Many courts have recognized implied limitations on an employer's right to terminate the employment relationship. Examples based on tort theory, often called "public policy exceptions," include the employee who is discharged for "whistle blowing," e.g., Sheets v. Teddy's Frosted Foods, Inc., 179 Conn. 471, 473, 427 A.2d 385, 386 (1980), or for refusing to engage in unlawful activities, eg., Tameny v. Atlantic Richfield Co., 27 Cal. 3d 167, 172-74, 610 P.2d 1330, 1332-34, 164 Cal. Rptr. 839, 841-43 (1980). An example based on the contract theory of an implied covenant of good faith is the discharge of an employee for opposing the negotiation of a "sweetheart contract," e.g., 
ployees with continuing obligations and limited alternatives it can be devastating. Thus, the main addition to the fundamental understanding that unions seek in collective agreements is job security. Occasionally unions achieve this by negotiating an exphicit guarantee of work. ${ }^{26}$ More frequently, the agreements provide partial job security by instituting a seniority system. ${ }^{27}$ More frequently still, the agreement protects job security by limiting the employer's power to discipline and discliarge. ${ }^{28}$

It is impractical for negotiators to spell out every possible offense that would allow an employer to discharge or discipline an employee. In fact, negotiators seldom attempt to include such a comprehensive list in the agreement. Instead they agree that discipline may be imposed only for "just cause" or some similar term. The just cause standard is so universal that arbitrators use it even when the agreement is silent. ${ }^{29}$ Thus, the fundamental understanding, as amended in the collective bargaining agreement, can be stated as follows: employees will provide "satisfactory" work, in return for which the employer will pay the agreed wages and benefits, and will contmue the employment relationship unless there is just cause to termmate it.

Just cause is obviously not a precise concept. It cannot be applied to a particular dispute by an employer or an arbitrator without analysis and the exercise of judgment. ${ }^{30}$ The concept is so vague, in fact, that it pro-

Pugh v. See's Candies, Inc., 116 Cal. App. 3d 311, 318-19, 328, 171 Cal. Rptr. 917, 919-20, 927 (1981). In the absence of special circumstances, however, an employer may usually discharge an employee at will. Recent developments regarding the employment-at-will doctrine are discussed in St. Antoine, The Revision of Employment-at-Will Enters a New Phase, 36 LAB. L.J. 563 (1985); Heinsz, The Assault on the Employment-at-Will Doctrine: Managerial Considerations, 48 Mo. L. REv. 855 (1983); Krauskopf, Employment Discharge: Survey and Critique of the Modern At-Will Rule, 51 UMKC L. REv. 189 (1983); Individual Rights in the Workplace: The Employment-at-Will Issue, 16 U. MICH. J.L. REF. 199 (1983); Note, Employee Handbooks and Employment-at-Will Contracts, 1985 DUKE L.J. 196.

26. The Bureau of National Affairs reported that $11 \%$ of its sample contracts contained clauses explicitly guaranteeing work or pay in some situations. 2 ColleCtIVE BARGAINING: NegotiATIONS AND CONTRACTS (BNA) § 53:1 (1983).

27. The Bureau of National Affairs reported that $89 \%$ of its sample contracts contained seniority provisions. Id. $\$ 75: 1$.

28. See supra note 1.

29. See supra note 2 and accompanying text.

30. The best attempt in an arbitration decision to give meaning to "just cause" was by Arbitrator Carroll R. Daugherty in Grief Bros. Cooperage Corp., 42 Lab. Arb. (BNA) 555, 557-59 (1964). Daugherty formulated a comprehensive but purely procedural scheme for determining just cause. His often-cited approach is worth quoting in full:

Few if any union-management agreements contain a definition of "just cause." Nevertheless, over the years the opinions of arbitrators in innumerable discipline cases have developed a sort of "common law" definition thereof. This definition consists of a set of guide lines or criteria that are to be applied to the facts of any one case, and said criteria are set forth below in the form of questions.

A "no" answer to any one or more of the following questions normally signifies that just and proper cause did not exist. In other words, such "no" means that the employer's 

a simple definition of "just cause," nor even a consensus on its applica-

disciplinary decision contained one or more elements of arbitrary, capricious, unreasonable, and/or discriminatory action to such an extent that said decision constituted an abuse of managerial discretion warranting the arbitrator to substitute his judgment for that of the employer.

The answers to the questions in any particular case arc to be found in the evidence presented to the arbitrator at the hearing thereon. Frequently, of course, the facts are such that the guide lines cannot be applied with slide-rule precision.

1. Did the Company give to the employee forewarning or foreknowledge of the possible or probable disciplinary consequences of the employee's conduct?

Note 1: Said forewarning or foreknowledge may properly have been given orally by management or in writing through the medium of typed or printed sheets or books of shop rules and of penalties for violation thereof.

Note 2: There must have been actual oral or written communication of the rules and penalties to the employee.

Note 3: A finding of lack of such communication does not in all cases require a "no" answer to Question No. 1. This is because certain offenses such as insubordination, coming to work intoxicated, drinking intoxicating beverages on the job, or theft of the property of the company or of fellow employees are so serious that any employee in the industrial society may properly be expected to know already that such conduct is offensive and heavily punishable.

Note 4: Absent any contractual prohibition or restriction, the company has the right unilaterally to promulgate reasonable rules and give reasonable orders; and same need not have been negotiated with the union.

2. Was the company's rule or managerial order reasonably related to the orderly, efficient, and safe operation of the capitalized Company's business?

Note: If an employee believes that said rule or order is unreasonable, he must nevertheless obey same (in which case he may file a grievance thereover) unless he sincerely feels that to obey the rule or order would seriously and immediately jeopardize his personal safety and/or integrity. Given a firm finding to the latter effect, the employee may properly be said to have had justification for his disobedience.

3. Did the company, before administering discipline to an employee, make an effort to discover whether the employee did in fact violate or disobey a rule or order of management?

Note 1: This is the employee's "day in court" principle. An employee has the right to know with reasonable precision the offense with which he is being charged and to defend his behavior.

Note 2: The company's investigation must normally be made before its disciplinary decision is made. If the company fails to do so, its failure may not normally be excused on the ground that the employee will get his day in court through the grievance procedure after the exaction of discipline. By that time there has usually been too much hardening of positions.

Note 3: There may of course be circumstances under which management must react immediately to the employee's behavior. In such cases the normally proper action is to suspend the employee pending investigation, with the understanding that (a) the final disciplinary decision will be made after the investigation and (b) if the employee is found innocent after the investigation, he will be restored to job with full pay for time lost.

4. Was the Company's investigation conducted fairly and objectively?

Note: At said investigation the management official may be both "prosecutor" and "judge," but he may not also be a witness against the employee.

5. At the investigation did the "judge" obtain substantial evidence or proof that the employee was guilty as charged?

Note: It is not required that the evidence be preponderant, conclusive or "beyond reasonable doubt." But the evidence must be truly substantial and not flimsy.

6. Has the company applied its rules. orders, and penalties evenhandedly and without discrimination to all employees?

Note 1: A "no" answer to this question requires a finding of discrimination and warrants negation or modification of the discipline imposed.

Note 2: If the company has been lax in enforcing its rules and orders and decides henceforth to apply them rigorously, the company may avoid a finding of discrimination by telling all employees beforehand of its intent to enforce hereafter all rules as written. 
tion to specific cases, but this does not mean the phrase is devoid of meaning. On the contrary, it is possible to make sense of the term and to give it substance. This can be done by viewing the just cause standard as an amended form of the fundainental understanding. Just cause, in other words, embodies the idea that the einployee is entitled to continued einployinent, provided he attends work regularly, obeys work rules, performs at some reasonable level of quality and quantity, and refrains from interfering with his einployer's business by his activities on or off the job. An employee's failure to meet these obligations will justify discipline. The employer's right to discipline an unsatisfactory employee may be stated expressly in the contract. Even where the contract is silent, however, the right is included among the "reserved rights" that inanagement retains froin its pre-union authority. ${ }^{31}$

The nature and severity of the employee's offense, among other things, will determine what form of discipline is appropriate. A sinall departure from "satisfactory" work inay result in a verbal or written warning. ${ }^{32}$ A inore serious or repeated offense inay produce a suspension without pay. ${ }^{33}$ In an extreme case, the employer may be justified in dis-

7. Was the degree of discipline administered by the company in a particular case reasonably related to (a) the seriousness of the employee's proven offense and (b) the record of the employee in his service with the company?

Note 1: A trivial proven offense does not merit harsh discipline unless the employee has properly been found guilty of the same or other offenses a number of times in the past. (There is no rule as to what number of previous offenses constitutes a "good," a "fair," or a "bad" record. Reasonable judgment thereon must be used.)

Note 2: An employee's record of previous offenses may never be used to discover whether he was guilty of the immediate or latest one. The only proper use of his record is to help determine the severity of discipline once he has properly been found guilty of the immediate offense.

Note 3: Given the same proven offense for two or more employees, their respective records provide the only proper basis for "discriminating" among them in the administration of discipline for said offense. Thus, if employee A's record is significantly better than those of employees $B, C$, and D, the company may properly give $\mathbf{A}$ a lighter punishment than it gives the others for the same offense: and this does not constitute true discrimination.

Although Daugherty's effort is commendable, he fails to explain why these procedural questions need to be answered. His approach lacks a theoretical basis grounded in the interests of management and labor in the discipline context. Although this article's theory of just cause raises many of Daugherty's procedural questions, it also presents an analytical framework for a systematic discussion of the nature of just cause.

31. See F. Elkouri \& E. Elkouri, How Arbitration Works 650-51 (4th ed. 1985).

32. See Challenge Mach. Co., 81 Lab. Arb. (BNA) 865, 868 (1983) (Roumell, Arb.); Washington Hosp. Center, 80 Lab. Arb. (BNA) 601, 606 (1983) (Rothschild, Arb.); Wallace-Murray Corp., 73 Lab. Arb. (BNA) 385, 386-87 (1979) (Seifer, Arb.).

33. See Municipal Court, 81 Lab. Arb. (BNA) 463, 464-65 (1983) (Draznin, Arb.); Lash Distrib., Inc., 74 Lab. Arb. (BNA) 274, 277-78 (1980) (Darrow, Arb.); Crosby Group, 72 Lab. Arb. (BNA) 787, 788 (1979) (Davis, Arb.). 
charging an employee. ${ }^{34}$ The employee may protest the discipline through the contractual grievance procedure. If the parties fail to resolve the grievance, the union may take the case to an impartial arbitrator for final and binding resolution. The question for the arbitrator is whether the einployee's conduct constituted a sufficiently serious breach of his obligation under the fundamental understanding to warrant the discipline imposed.

The fundamental understanding forms the very core of just cause. Management seeks efficient production fron its workforce and engages individual einployees to achieve that goal. When an einployee fails to fulfill the employer's reasonable expectations, he breaches his obligations under the fundainental understanding. On the other hand, when an employer fires an enıloyee for an illegitinate reason, it breaches its obligation under the amended version of the fundamental understanding. The eniployee's offense and the employer's decision to fire can both be tested against the just cause standard.

The fundaniental understanding, as amended in the collective bargaining agreement, is a useful tool for the developinent of a theory of just cause, but further refineinents are possible. The arbitrator can better identify the types of prohibited behavior and the appropriate levels of discipline by understanding the interests of management and the union in disciplimary situations.

\section{MANAGEment's INTERests}

Why would management discipline an employee? Whin or prejudice explain sone disciplinary decisions, ${ }^{35}$ but such cases are rare. The profit motive alone discourages arbitrary discipline. ${ }^{36}$ Wrongful or disproportionate discipline creates employee dissatisfaction, ${ }^{37}$ which in turn makes it more difficult to hire and retain qualified einployees. In particular, wrongful discharge inay inipose significant costs on an einployer, who nuust seek out, employ, and train a replacement for the terminated

34. See Care Inns, Inc., 81 Lab. Arb. (BNA) 687, 694 (1983) (Taylor, Arb.) (janitor discharged for sexual assault of nurse's aide); Metropolitan Transit Auth., 81 Lab. Arb. (BNA) 655, 656 (1982) (Allen, Arb.) (bus driver who shot a motorist was discharged for possessing a gun on bus).

35. See Peterson, Management Efficiency and Collective Bargaining, 1 INDUS, \& LAB. REL. REV. 29, 39 (1947) (unorganized workers often have no protection against discipline based on whim or prejudice).

36. See generally Myers, Concepts of Industrial Discipline, 9 Proc. NAT'L ACAD. ARB. 59, 60 (1956).

37. See S. Slichter, J. Healy \& E. Livernash, The Impact of Collective Bargaining on MANAGEMENT 624 (1960). 
worker. ${ }^{38}$ The employer's common law authority to suspend or discharge workers at will is thus no indication of his actual willingness to use that authority in a capricious manner.

Most disciphne is imposed for more rational purposes. There are at least three possible motivations for employee discipline: (1) rehabilitation, (2) deterrence, which may be either specific or general, and (3) protection of profitability. Rehabilitation is the most obvious objective. An employee who seeins to be developing poor work habits, such as absenteeism or carelessness, may, as the result of disciphnary prodding, become fully satisfactory. Perhaps the employee's mistakes stemmed from some correctable personal problem or a lack of awareness as to their seriousness. By applying discipline in gradually mcreasing doses, the employer might impress upon the employee the need for change. The objective is to cure a specific problem and make the employee's work satisfactory. ${ }^{39}$

Specific deterrence is closely related to rehabilitation. The employer's objective is to deter an einployee from repeating a certain error by imposing one penalty and threatening to impose a more serious one in the future. ${ }^{40}$ Where the employee's conduct indicates that rehabilitation is impossible, specific deterrence will be ineffective. In such cases, the employer will discharge the employee, having determined that he is incorrigible. ${ }^{41}$

Both the rehabilitation and specific deterrence objectives reflect the einployer's attempt to predict an einployee's future performance on the basis of past performance. If the employee's past performance indicates that he could do satisfactory work in the future, soine discipline short of discharge is appropriate. If, on the other hand, the employee's prior conduct indicates an inability to fulfill the essential elements of the job, termination may be the appropriate decision.

38. See Montgomery Ward \& Co., 80 Lab. Arb. (BNA) 321, 323 (1983) (Dobry, Arb.); Alexander, Concepts of Industrial Discipline-Discussion, 9 Proc. NAT'L ACAD. ARB. 76, 80 (1956) (costs to employer will vary with labor market for skills required).

39. See Montague Mach. Co., 78 Lab. Arb. (BNA) 172, 175 (1982) (Bornstein, Arb.); Standard Shade Roller Div., 73 Lab. Arb. (BNA) 86, 90 (undated) (Dawson, Arb.); Southwest Elec. Co., 54 Lab. Arb. (BNA) 195, 196 (1969) (Bothwell, Arb.); Whitewater Elecs., 36 Lab. Arb. (BNA) 1442, 1446 (1961) (Mueller, Arb.). See generally Alexander, supra note 38, at 79-80.

40. Some cases illustrating the use of discipline for specific deterrence are Coca-Cola Bottling Co., 79 Lab. Arb. (BNA) 1122, 1127 (1982) (Garnholz, Arb.), and Alfredo Mfg., 66 Lab. Arb. (BNA) 1005, 1011 (1976) (Helfeld, Arb.).

41. See, e.g., United Elec. Supply Co., 82 Lab. Arb. (BNA) 921, 926 (1984) (Madden, Arb.); Apcoa, Inc., 81 Lab. Arb. (BNA) 449, 452 (1983) (Hewitt, Arb.); Pacific Northwest Bell Tel. Co., 81 Lab. Arb. (BNA) 297, 306 (1983) (Gaunt, Arb.); Koenig Iron Works, 53 Lab. Arb. (BNA) 594, 597 (1969) (Ray, Arb.). 
For example, consider the employee who has been adequately trained and counselled, but nevertheless accumulates a record of substandard performance. At some point, a reasonable observer would conclude that the employee has proven himself unable to meet the basic requirements of his job. Similarly, an employee who continues to attend work erratically, after receiving warnings and suspensions, deinonstrates his inability or unwillingness to fulfill a critical part of his job. In both instances, the employee's past performance determines management's prediction about future performance. 42

Past performance is not always an accurate predictor. Even when it is not, discipline may nevertheless be justified. Management establishes formal and informal work rules to guide the conduct of employees while they are on the employer's premises. ${ }^{43}$ In every large group of workers, there are some individuals who will inhibit productivity. The possibilities are almost endless: physical disruption, negligence, theft, intoxication, and so on. Management may decide to discipline an employee who violates a work rule even if there is no reason to believe it will happen again. In that case, management's objective is to protect the integrity of its rules by general deterrence, that is, by making an example of one employee in order to keep others from breaking the rules. ${ }^{44}$ Once again, management's decision looks to the future, but in this case it is the future conduct of other employees that is of primary concern.

The legitimacy of a decision to discipline an employee for the purpose of general deterrence depends upon the importance of the employer's interest protected by the rule, and upon the necessity of discipline to deter others from similar misconduct. Take the case of an employee subject to unusual stress who strikes his foreman. The protection of supervisors is critical in any workplace; fear of physical reprisal must not inhibit supervisors from assigning work, enforcing rules, and disciplining employees. As a result, most arbitrators would sustain a discharge for this offense on general deterrence grounds, even though it was

42. See McGraw-Edison, 81 Lab. Arb. (BNA) 403, 408 (1983) (Role, Arb.); Safeway Stores, 79 Lab. Arb. (BNA) 742, 748-49 (1982) (MacLean, Arb.); Caterpillar Tractor Co., 67 Lab. Arb. (BNA) 203, 210 (1976) (Wolff, Arb.).

43. Georgia Kraft Co., 71 Lab. Arb. (BNA) 222, 225 (1978) (Spritzer, Arb.) ("It is widely accepted in the field of industrial relations and labor arbitration that a company may legitimately promulgate rules governing ... the conduct of its employees while on the job."); Ford Motor Co., 3 Lab. Arb. (BNA) 779, 781 (1944) (Shulman, Arb.). See generally A. GouldNER, PATTERNS OF INDUSTRIAL BUREAUCRACY 163, 179 (1954).

44. See Zia Co., 82 Lab. Arb. (BNA) 640, 642 (1984) (Daughton, Arb.) (without discharging the grievant it would be "impossible . . to enforce Company policy toward any other employee"); Food Giant Inc., 79 Lab. Arb. (BNA) 833, 834 (1982) (Dallas, Arb.) (it would be "suicide" not to enforce anti-theft rule with discharge); Reiter Foods, 77 Lab. Arb. (BNA) 526, 529 (1981) (Hanes, Arb.) (severe discipline will deter others). 
shown that the employee would be unlikely to repeat the misconduct. ${ }^{45}$ Thus, "[e]ven if there is no substantial risk that the grievant would slug his boss a second time, reinstatement might well entail so much embarrassment, resentment, and strain as to be impracticable."46 Violation of less critical rules, in contrast, would not justify discharge for general deterrence.

The final purpose for which management may discipline an employee, protection of profitability, is something of a catch-all. Certain employee conduct, though not prohibited by a specific rule, may still interfere with the employer's operation of the enterprise. For instance, employees can mar a carefully nurtured public image and can harm relationships with customers or supphers. ${ }^{47}$ Discipline up to and including dismissal might be appropriate even when it cannot be directly tied to motives of rehabilitation or deterrence. The largest category of employee conduct falling under this third objective involves off-duty activity.

The generally accepted rule is that an einployer may not discipline an employee for off-duty conduct unless the conduct can be shown to harm the employer. ${ }^{48} \mathrm{~A}$ few examples will illustrate the rule. Suppose a day-care worker molests a child during his off-duty hours and, following conviction, is placed on probation. Continued employment of the worker would obviously discourage customers. A discharge would almost certainly be upheld, even though no work rule was violated, the employee's work was otherwise satisfactory, and criminal prosecution alone was a sufficient deterrent for this employee..$^{49}$ Other examples include the bank officer whose pre-employment conviction for embezzling a client's funds suddenly comes to light, ${ }^{50}$ and the employee who is convicted of drug

45. See Freeman United Coal Co., 82 Lab. Arb. (BNA) 861, 866 (1984) (Roberts, Arb.) (discharge warranted "as a deterrent to insure that it will never happen again"); Allied Aviation Serv. Int'l, 60 Lab. Arb. (BNA) 441, 443 (1973) (Turkus, Arb.); Wheland Foundry Div., 54 Lab. Arb. (BNA) 259, 260 (1970) (Hon, Arb.).

46. Ross, Discussion, 17 Proc. Nat'l ACAD. ARB. 144, 151 (1964).

47. See Regional Transp. Dist., 80 Lab. Arb. (BNA) 1225, 1233-34 (1983) (Eaton, Arb.); Hughes Air Corp., 73 Lab. Arb. (BNA) 148, 157 (1979) (Barsamian, Arb.).

48. See Joy Mfg. Co., 68 Lab. Arb. (BNA) 697, 701 (1977) (Freeman, Arb.); General Tire Serv., 52 Lab. Arb. (BNA) 1279, 1281-82 (1969) (Todd, Arb.); W.E. Caldwell Co., 28 Lab. Arb. (BNA) 434, 436-47 (1957) (Kesselman, Arb.).

49. See Dodds Livorno Am. High School, 82 Lab. Arb. (BNA) 761, 766 (1983) (Zack, Arb.) (alleged homosexual conduct with a student); Social Security Admin., 80 Lab. Arb. (BNA) 725, 728 (1983) (Lubic, Arb.) (alleged sexual activity with minor child).

50. Cf. Gold Kist, Inc., 77 Lab. Arb. (BNA) 569, 575 (1981) (Statham, Arb.) ("a fraudulent entry of a material fact" on an employment application "willfully made to deceive the employer vests in the employer the right to terminate the employee"). 
dealing during off-duty hours. ${ }^{51}$ These situations call for the most careful evaluation by management im order to avoid overreaction and reliance on unfounded fears, but the employer's legitimate interest in avoiding harm to business relationships is entitled to protection.

The just cause standard precludes one common objective for discipline-retribution. Management may not discipline an employee merely to punish him for his transgressions. Indeed, it has no economic interest in doing so. Individual managers may desire retribution, but a business entity has no legitimate interest beyond productivity and profitability.

All of the legitimate management interests in discipline are consistent with the fundamental understanding. Rehabilitation and specific deterrence are aimed at improving the transgressing employee's work. General deterrence serves to reinforce the work rules which all employees must observe if the business is to prosper. Finally, protection of profitability justifies prohibition of conduct that harms the employer's business relations.

\section{THE UNION'S INTERESTS}

What does a union seek in a discharge or discipline case? A cynic might argue that the umion's goal is unqualified job security. Like the extreine management ideal of unlimited discretion, such a union goal cannot be considered legitimate; nor does it reflect true union interests. A union cannot reasonably expect management to carry on its employment rolls someone who has breached the fundamental understanding. A union may certainly question the extent to which a particular instance of employee conduct may harm productivity, but it must acknowledge that an einployee's failure to meet his obligations works to the detriment of other employees as well as the employer. In the short run, an unsatisfactory employee simply makes the jobs of co-workers more difficult. In the long run, continued tolerance of substandard performance will endanger the employer's competitive position, and that, in turn, will threaten the wages and even the jobs of the rest of the workforce. The econoimic welfare of workers and management is interdependent. 52

51. See City of Wilkes-Barre, 74 Lab. Arb. (BNA) 33, 35-36 (1980) (Dunn, Arb.); Joy Mfg. Co., 68 Lab. Arb. (BNA) 697, 701 (1977) (Freeman, Arb.); National Steel Corp., 60 Lab. Arb. (BNA) 613, 616-17 (1973) (McDermott, Arb.).

52. See Florsheim Shoe Co., 74 Lab. Arb. (BNA) 705, 709 (1980) (Roberts, Arb.) (poor productivity "would impair the Company's ability to make a profit, to grant wage increases in future negotiations to good productive employees and, indeed, a Company's very ability to provide jobs"); see also Brown, The Shifting Distribution of the Rights to Manage, in THE PROFEssion of LABOR ARBITRATION 133, 140 (J. McKelvey ed. 1948). 
The union's real interest in disciplinary nıatters is fairness. A union pursues this interest in a variety of ways. First, it seeks fairness in disciplinary procedures. For exaniple, eniployees niust have actual or constructive notice as to their work obligations. ${ }^{53}$ Posted disciplinary rules are fairly comnion, but even in the absence of such rules, arbitrators reasonably presume that employees are aware of basic, though unwritten, behavioral standards. ${ }^{54} \mathrm{~A}$ union also seeks fairness in the administration of discipline. Disciplinary measures must be based on facts; managenıent must ascertain what actually occurred before it imposes discipline. ${ }^{55}$ Managenient nuust also give the enıployee an opportunity to explain and must allow him union representation during the investigation, if he so requests. ${ }^{56}$ Finally, discipline should be iniposed in gradually increasing degrees. ${ }^{57}$ These concerns for procedural fairness inight be terined "industrial due process." 58

A umion will also seek procedural fairness in the arbitration process, particularly in the allocation of the burden of proving just cause. A disciplimary grievance, like other grievances, alleges that the employer

53. Piggly Wiggly T-212, 81 Lab. Arb. (BNA) 808, 815 (1983) (Nelson, Arb.) (employees must "be put on clear notice as to exactly what they are doing that is inappropriate or unacceptable, and warned that if that inappropriate or unacceptable behavior continues, discipline and/or discharge will result"); see New Castle State Hosp., 77 Lab. Arb. (BNA) 585, 590 (1981) (Deitsch, Arb.) (employer has responsibility to the employees to develop "unequivocal and understandable rnles and regulations"); Owens-Illinois, Inc., 76 Lab. Arb. (BNA) 994, 997 (1981) (Koven, Arb.); Stella D'Oro Biscuit Co., 48 Lab. Arb. (BNA) 349, 350 (1967) (Cahn, Arb.).

54. See Freeman United Coal Co., 82 Lab. Arb. (BNA) 861, 865-66 (1984) (Roberts, Arb.) (no need to post rule because employees should know that operating machinery while intoxicated is dangerous and will subject them to discipline); Holiday Inns, 82 Lab. Arb. (BNA) 597, 601 (1984) (Concepcion, Arb.) (leaving a burning candle concealed in a narrow space containing paper and wood debris, although not forbidden by any promulgated rule, was careless and dangerous, and justified discharge of maintenance engineer); University of Cal., 78 Lab. Arb. (BNA) 1032, 1037 (1982) (Ross, Arb.) (even without knowledge of written policy, common sense should dictate to einployee that it was improper to arrange for eniployer to purchase services from firm in which employee's husband had a business interest without disclosing such interest).

55. See, e.g., Great Midwest Mining Corp., 82 Lab. Arb. (BNA) 52, $55-66$ (1984) (Mikrut, Arb.); American Bakeries Co., 77 Lab. Arb. (BNA) 530, 534 (1981) (Modjeska, Arb.) (failure to investigate violates "basic notions of fairness and due process"); McGraw-Edison Serv., 76 Lab. Arb. (BNA) 1003, 1005 (1981) (Kelliher, Arb.); Gulf Printing Co., 61 Lab. Arb. (BNA) 1174, 1179 (1974) (Lilly, Arb.).

56. See Associated Grocers of Colo., 82 Lab. Arb. (BNA) 414, 418 (1984) (Smith, Arb.) (company was remiss in failing to give grievant an opportunity to be heard prior to discharge).

57. See Metropolitan Atlanta Rapid Transit Auth., 80 Lab. Arb. (BNA) 829, 835 (1983) (Singer, Arb.); Montague Mach. Co., 78 Lab. Arb. (BNA) 172, 175-76 (1982) (Bornstein, Arb.); United Tel. Co., 58 Lab. Arb. (BNA) 1246, 1253 (1972) (Seinsheinier, Arb.).

58. See Mor-Flg, Mor-Flo Indus., 77 Lab. Arb. (BNA) 889, 893 (1981) (Nigro, Arb.) ("A fundamental due process requirement in discipline for just cause is that the employee be treated fairly."); see also Fleming, Some Problems of Due Process and Fair Procedure in Labor Arbitration, 13 STAN. L. Rev. 235 (1961); Wirtz, Due Process of Arbitration, 11 Proc. NaT'l ACad. ARb. 1 (1958). 
breached the collective bargaining agreement. Although the burden of proof usually rests with the party asserting the breach, the union will seek to shift the burden of proof to management when the case involves discipline. The fundamental understanding, as amended by the collective agreement, provides for continued employment unless there is just cause for discipline. Management, in the union's view, thus bears the burden of demonstrating just cause. ${ }^{59}$ It has singled out an individual employee for disciplinary action or termination, it knows why it took the action, and for that reason it should bear the burden of explaining why discipline is justified.

The second way $\mathrm{m}$ which a union seeks "fairness" in discipline is through consistent treatment of similar cases. For example, if one employee is not pumished for certain conduct, co-workers who engage in the same conduct should be treated in the same manner. Like cases should be treated ahke. ${ }^{60}$ In a disciplinary situation, a union seeks what might be termed "industrial equal protection."

Finally, a umion seeks "fairness" for the disciplined individual by compelling management to consider mitigating factors. ${ }^{61}$ Perhaps the most important of these is the employee's work record.62 For any given offense, an employee with a long record of excellent work and no prior discipline should be treated more lemently than a junior employee with a history of unsatisfactory work and several prior offenses. ${ }^{63}$ Other mitigating factors may be tied to the particular offense. If two employees have been fighting, the aggressor deserves more severe discipline than the victim. ${ }^{64}$ In appropriate cases, an employee's attitude, demeanor, and

59. See O. Fairweather, Practice and Procedure in Labor Arbitration 254 (2d ed. 1983).

60. See Western Paper Box, 81 Lab. Arb. (BNA) 917, 921 (1983) (Concepcion, Arb.); Transit Management, Inc., 77 Lab. Arb. (BNA) 845, 849 (1981) (Foster, Smith, Warlick, Arbs.); Visador Co., 73 Lab. Arb. (BNA) 578, 579 (1979) (Seifer, Arb.).

61. See, e.g., Southwest Detroit Hosp., 82 Lab. Arb. (BNA) 491, 492 (1984) (Ellman, Arb.); Youngstown Hosp. Ass'n, 82 Lab. Arb. (ENA) 31, 33-35 (1983) (Miller, Arb.); Safeway Stores, 79 Lab. Arb. (BNA) 742, 746-47 (1982) (MacLean, Arb.); County of Monroe, 72 Lab. Arb. (BNA) 541, 543 (1979) (Markowitz, Arb.); Georgia Kraft Co., 71 Lab. Arb. (BNA) 222, 227 (1978) (Spritzer, Arb.).

62. See, e.g., Union Carbide Corp., 81 Lab. Arb. (BNA) 864, 865 (1983) (White, Arb.); Dayton Power \& Light Co., 80 Lab. Arb. (BNA) 19, 21-22 (1982) (Heinsz, Arb.). See generally Labig, Helburn \& Rodgers, Discipline History, Seniority, and Reason for Discharge as Predictors of PostReinstatement Job Performance, 40 ARB. J., Sept. 1985, at 44 (good pre-discharge discipline record is a reliable predictor of good job performance after reinstatement).

63. See Montague Mach. Co., 78 Lab. Arb. (BNA) 172, 176 (1982) (Bornstein, Arb.).

64. See Transportation Labor Inc., 76 Lab. Arb. (BNA) 1249, 1250 (1981) (Sheehan, Arb.); Kaiser Found. Health Plan, 73 Lab. Arb. (BNA) 1057, 1058 (1979) (Herring, Arb.). 
other personal factors might warrant mitigation of the penalty. ${ }^{65}$ The union thus seeks fairness through individualized treatment.

This third goal initially may appear to conflict with the union's interest in equal protection. The two objectives, however, are coinpatible. Like cases should be treated ahike, but different cases should be treated differently. The just cause standard requires reasonable disciplime in each case; it does not require that each category of offense carry a single mandatory penalty.

Reconciling the goals of equal protection and individualized treatment is not always easy. A union may argue one day that an employee deserves leniency because of his semiority or his personal problems. The very next day, however, the union may argue that another employee, unable to show these mitigating factors, should be treated no more harshly than the first employee. Although such union advocacy is to be expected, the arbitrator should reject this arguinent. An einployer may and should consider relevant individual factors before imposing discipline. As long as the employer uses relevant distinctions and applies them consistently, the resulting differences in disciplime should not be disturbed.

In sum, a umion seeks disciplinary "fairness" in three ways: (1) industrial due process, (2) industrial equal protection, and (3) individualized treatment achieved through consideration of specific initigating factors. These objectives are consistent with the fundamental understanding, as amended in the collective bargaining agreement; the employee's expectation is that he will not be disciplined if his work and conduct are satisfactory. Industrial due process guarantees an accurate evaluation of his work and conduct. Industrial equal protection guarantees that the definition of "satisfactory" work will be fixed at a certain standard-a relatively stable reference point by which an employee can plan his behavior. Individualized treatment ensures that special circumstances making the usual standards inappropriate will be given due consideration.

Thus both management and union interests in discipline are consistent with the fundamental understanding. The next question is whether the interests are consistent with each other. If so, a theory of just cause premised on the fundamental understanding can be developed and applied, without sacrificing the objectives of either party.

65. See Kansas City Power \& Light Co., 78 Lab. Arb. (BNA) 267, 273-74 (1982) (Newmark, Arb.); Oolite Indus., 77 Lab. Arb. (BNA) 838, 845 (1981) (Greene, Arb.). 


\section{The CONGRUENCE OF MANAgEMENT AND UNION INTERESTS}

The legitimate interests of management and labor in discipline and discharge cases are reconcilable. Using the fundamental understanding, it is possible to develop a theory of just cause that is consistent with the interests of both parties.

Management can have little objection to a fair and consistent system of discipline. Similarly, a union has no cause to object to disciplinary actions occasioned by employee conduct that significantly interferes with management's legitimate concern for production. Although the parties may differ as to whether a particular disciplinary system is fair or whether a given type of behavior warrants a certain measure of discipline, they can agree that the legitimate interests of management and labor provide the standards against which management's action must be judged.

In order to establish just cause for disciplinary action, management must first show that its interests were significantly affected by the employee's conduct. For instance, when an eniployee has been discharged for violating a work rnle, managennent nnay show that the employee's prior conduct demonstrates he is unlikely to fulfill the obligations of his job in the future. 66 Alternatively, management may show that even though the employee is unlikely to repeat the wrongful conduct, it is important to deter other employees from such conduct and that discharge is the only effective form of deterrence. Either of these two explanations would establish a prima facie showing of just cause. In order to rebut this showing of just cause, a union must prove that nanagement failed to give the employee industrial due process or industrial equal protection, or failed to consider mitigating factors. For example, the union may show that management took disciplinary action without adequate investigation, or singled out the employee for discipline when others had been excused for the sanie conduct, or ignored nitigating circumstances sucl1 as illness or provocation.

Union and managenient interests are fundamentally congruent, though it may not seen1 so to the parties. Managenient's objective of productive efficiency is served by industrial due process. For example, it is in the eniployer's interest to give eniployees adequate notice of their obligations. If a conipany wants employees to neet their perforniance obligations, it must, at the very least, let them know what those obligations are. Similarly, management's objective of productive efficiency is served by investigating the facts of a case before imposing discipline. A

66. In the case of a second or third violation, the mere fact of prior discipline may establish significant doubt about future satisfactory work. 
wrongful accusation undermines the integrity of the disciplinary systein, creates resentment, and, in a discharge case, deprives management of a satisfactory employee, while inposing on it the costs of obtaining and training a replacement. Just as employees must know that when they fulfill their obligations they will not be disciplined, employees must also know that when they fail, they will be disciplined-but proportionately and equally. Thus, management benefits by responding to the union's interest in industrial due process.

Management also benefits from industrial equal protection. If like cases are not treated alike, employees will be confused as to the governing standards or misled into believing that substandard conduct will be tolerated.

Management's desire for efficiency is also congrnent with the union's interest in individualized treatment of employees througli consideration of initigating circuinstances. This congruency, however, is not obvious. The consideration of mitigating circumstances does not detract from management's interest im productive efficiency. For example, consider the einployee fired for poor attendance. Though his recent attendance violates standards, his long and productive work record may indicate that he is capable of performing the essential responsibilities of lis job in the future and that his wrongful conduct was atypical. In such a case, management's interest in productive efficiency might actually be furthered by retention of the employee combined with efforts to cure the problem. On the otlier liand, consider the employee who is fired for striking his supervisor, a "mortal sin" in the workplace. In such a case, a long and satisfactory work record should not mitigate lis discharge. The broken rule is so important that firing even a senior employee can be justified as a necessary deterrent for other workers.

\section{A THEORY OF Just CAUSE}

The legitimate interests of managenient and labor regarding discipline are consistent both with the fundamental understanding and with each other. From this congruence, a theory of just cause can be derived, a theory which accoinmodates the parties' needs and reflects their inutual understanding.

A. Just cause for discipline exists only when an eniployee lias failed to ineet his obligations under tlie fundanental understanding of the einployinent relationslip. The einployee's general obligation is to provide satisfactory work. Satisfactory work lias four components:

1. Regular attendance.

2. Obedience to reasonable work rules. 
3. A reasonable quality and quantity of work.

4. Avoidance of conduct, either at or away from work, which would interfere with the employer's ability to carry on the business effectively.

B. For there to be just cause, the discipline inust further one or more of manageinent's three legitimate interests:

1. Rehabilitation of a potentially satisfactory employee.

2. Deterrence of similar conduct, either by the disciplined employee or by other employees.

3. Protection of the employer's ability to operate the business successfully.

C. The concept of just cause includes certain employee protections that reflect the umion's interest in guaranteeing "fairness" in disciplinary situations.

1. The employee is entitled to industrial due process. This includes:

a. actual or constructive notice of expected standards of conduct and penalties for wrongful conduct;

b. a decision based on facts, determined after an investigation that provides the einployee an opportunity to state his case, with umion assistance if he desires it;

c. the imposition of discipline in gradually increasing degrees, except in cases involving the most extreme breaches of the fundamental understanding. In particular, discharge may be imposed only when less severe penalties will not protect legitimate management interests, for one of the following reasons: (1) the employee's past record shows that the unsatisfactory conduct will continue, (2) the most stringent form of discipline is needed to protect the system of work rules, or (3) continued employment would inevitably interfere with the successful operation of the business; and

d. proof by inanagement that just cause exists.

2. The employee is entitled to industrial equal protection, which requires like treatinent of like cases.

3. The enployee is entitled to individualized treatment. Distinctive facts in the employee's record or regarding the reason for discipline inust be given appropriate weight.

\section{Application of the Theory of Just Cause}

While labor arbitrators frequently decide discharge and discipline cases, they rarely discuss the concept of just cause in other than con- 
clusory terms. ${ }^{67}$ Even so, most arbitration awards in reported discipline decisions can be explained by this article's theory of just cause. Deviations from the theory probably result from the fact that there has been little systematic evaluation of the nature of just cause. The following examples illustrate the theory of just cause.

\section{A. Determination of "Satisfactory" Work.}

Illustration 1: Regular Attendance. One of an employee's primary responsibilities is to report to work in a timely fashion. If an employee fails to fulfill this obligation, discipline may be imposed. Continual tardiness or absenteeism may justify discharge.

For example, consider the case of an employee who had been tardy or absent eleven times during a fourteen month period. After a few absences, management discussed the problem with the employee. Further absences resulted in a letter of warning. As a result of continued absences, the employer imposed a three-day suspension, followed by a tenday suspension. Finally, the company fired the employee. The arbitrator held that the discharge was justified, characterizing the employee's attendance record as "dismal" and the company's attendance policy as necessary to maintaining the efficiency of its operations. 68

The obligation of regular attendance is not absolute, however. Where absences are for a good reason, and the reason no longer exists, the hikely prospect of regular attendance in the future may make discharge unreasonable. In a recent case, an employee's absenteeism, which was primarily the result of an industrial injury and a gunshot wound, initially had been considered excused by the company. Management later decided to discharge the employee, claiming that his absences were excessive. Because there was no evidence that the injury, though longterm, would prevent the employee from meeting his attendance obligations in the future, the arbitrator sustained the employee's grievance. ${ }^{69}$

The legitimacy of discipline for unsatisfactory attendance turns largely on a prediction of the employee's future conduct. A few isolated

67. See supra notes 5-9 and accompanying text.

68. Gulf Oil Co., 69 Lab. Arb. (BNA) 128, 131 (1977) (Drotning, Arb.); see also Angelus Sanitary Can Mach. Co., 68 Lab. Arb. (BNA) 973, 976 (1977) (Ashe, Arb.) (dismissal upheld because employee was absent more than other employees, the absences had an adverse effect on company efficiency, and the company counseled the employee and used progressive discipline); North Am. Rockwell Corp., 54 Lab. Arb. (BNA) 178, 180-81 (1969) (Volz, Arb.) (dismissal upheld where employee was repeatedly warned about absenteeism, but continued to act indifferently).

69. Oglebay Norton Co., 82 Lab. Arb. (BNA) 652, 654-55 (1984) (Duda, Arb.); see also Caterpillar Tractor Co., 67 Lab. Arb. (BNA) 203, 210 (1976) (Wolff, Arb.) (evidence insufficient to predict that employee was unable to work in the future). 
mcidents of absenteeism simply do not establish the facts necessary to predict continued problems, nor does a pattern of absenteeism based upon a condition that is unlikely to recur, such as an industrial injury. A pattern of absenteeism based upon a condition, such as an industrial injury, that is unlikely to recur, also will not support a prediction of future absences. However, when the evidence demonstrates that excessive absenteeism is likely to contimue in the future, the employer has shown a breach of the einployee's obligation to provide "satisfactory" work.

Illustration 2: Observance of Reasonable Work Rules. Work rules regulate employee conduct im order to maximize both the safety of other employees and the productivity of the company. Breach of reasonable work rules is thus a legitimate ground for discipline.

In one case, an employee was discharged following a fight that began as simple bantering and ended with a knifing. The company, whose rules prohibited fighting on the premises, disagreed with the union's characterization of the event as mere horseplay. The arbitrator upheld the firing, stating that certam standards of conduct must be maintained in the workplace. ${ }^{70}$ If the employer could not discipline employees for such infractions, it would be impossible to maintam the minimum order needed for protection of other employees and for productivity.

In a second case, an employee was discharged for violating a chemical manufacturer's rule prohibiting smoking in designated "no smoking" areas. The arbitrator stated that the company had a legitimate interest in himiting smoking to certain specified areas-indeed, it was "imperative" that management restrict this conduct. Individual employees could not be allowed to weigh for themselves the risks and advantages of smoking in desiguated "no smoking" areas. ${ }^{71}$

Observance of reasonable work rules is necessary to ensure the satisfactory work to which the employer is entitled under the fundamental understanding. Of course, even when a work rule is valid, management must establish that the rule was violated by the disciplined employee. For example, an employee who was fired for being rude to customers was reinstated when management could present no witnesses with first-hand

70. Eagle Ottawa Leather Co., 82 Lab. Arb. (BNA) 493, 494 (1984) (Jason, Arb.); see also Russer Foods, 75 Lab. Arb. (BNA) 305, 306 (1980) (Grant, Arb.) (just cause existed for dismissing einployee for horseplay that involved setting fires on company property); Kroger Co., 75 Lab. Arb. (BNA) 290, 292 (1980) (Berns, Arb.) (just cause existed for dismissing employee who set fire to coworker's apron).

71. Olin Corp., 81 Lab. Arb. (BNA) 644, 647 (1983) (Nicholas, Arb.). But cf. Converters Ink, 68 Lab. Arb. (BNA) 593, 596 (1977) (Seinbower, Arb.) (mitigating circumstances in favor of employee inay be considered where lighting of cigarette was involuntary, with no scienter on employee's part). 
knowledge of the alleged incidents. ${ }^{72} \mathrm{Had}$ the employer presented the arbitrator with adequate proof of a breach, discipline would certainly have been warranted.

Illustration 3: Reasonable Quantity and Quality of Work. An employee is hired to produce a reasonable quantity of work at an expected level of quality. When an employee does not fulfill his obligation to produce "satisfactory" work, he may be subject to disciphine and, ultimately, to discharge. ${ }^{73}$ At times, an employee may be physically incapable of performing assigned work; this is not normally considered an occasion for "discipline," because the employee may not be at fault for his condition. Nonetheless, the just cause standard applies, and satisfactory work must be produced.

What is "satisfactory" work will vary from case to case. A recent decision reveals that the definition of "satisfactory" depends on the circumstances. A discharged "Driver Salesperson's" low productivity was the result of a temporary disability - an occupational leg mjury. A company rule required driver salespersons to deliver thirty cases of soft drinks per hour. The arbitrator concluded that this quantity standard, while generally reasonable, was unreasonable when applied to the dismissed employee because his leg injury prevented him from meeting the standard. The driver should have been required to perform only the amount of work reasonable in light of his injury. ${ }^{74}$

Permanent or extended disabilities are another matter. An employee may become physically or psychologically incapable of performing a reasonable quantity or quality of work. If so, dismissal is justified because an employer is entitled to a fair day's work in return for payment of wages. ${ }^{75}$ Thus, an arbitrator correctly held that an employee who had a chronic asthma condition, with unusual allergic sensitivity to various industrial chemical fumes, was rightfully discharged because he could no

72. Dyer's Chop House, 82 Lab. Arb. (BNA) 198, 202 (1984) (Ray, Arb.); see also Excelsior Truck Leasing Co., 71 Lab. Arb. (BNA) 470, 472 (1978) (Votaw, Arb.).

73. In one case, a company fired a lathe operator who consistently failed to meet established production standards after he had received three warning notices. The arbitrator upheld the discharge, concluding that the quantity and quality of the employee's work fell below that reasonably expected by the company. General Elec. Co., 74 Lab. Arb. (BNA) 578, 580 (1980) (Schor, Arb.); see also Mobay Chem. Corp., 77 Lab. Arb. (BNA) 219, 221-22 (1981) (Lubow, Arb.).

74. Universal Foods Corp., 82 Lab. Arb. (BNA) 105, 112 (1984) (Belcher, Arb.); see also Price Pfister Brass Mfg. Co., 63 Lab. Arb. (BNA) 89, 93 (1974) (Fellman, Arb.) (unreasonable for employer to insist that employee continue to operate certain machines after she was injured). Of course, an employer can lay off an employee who is unable to produce a satisfactory quantity of work.

75. Humanitarian concerns may justify payments from the public treasury or from social insurance programs, but they do not require an employer to continue paying an unproductive worker. 
longer perform his job adequately. ${ }^{76}$ Similarly, the discharge of an epileptic employee was held to be justified because continued employment would have endangered other employees. ${ }^{77}$ Discharge in such cases is not for rehabilitation or deterrence. It can be explained only by reference to the fundamental understanding.

Management may discipline or terminate employees in its pursuit of productivity. Poor work performance warrants discipline if the standards used to evaluate that performance are reasonable. An employee may be fired when he fails to correct his work performance after progressive discipline or may be terminated when he becomes physically or psychologically incapable of performing his assigned work. In those instances, the employer can justify dismissal by showing that the employee will be unable to meet his obligation to produce a reasonable quantity and quality of work.

\section{Illustration 4: Avoidance of Conduct Interfering with the Successful} Operation of the Company. Employee misconduct away from the workplace may result $\mathrm{m}$ discipline if management can prove that the activity interferes with the einployer's ability to carry on its business effectively. One typical situation involves an employee who, while off-duty, commits a crime that casts doubt upon his ability to continue to perform his job adequately. Thus, a supermarket had just cause for the discharge of a clerk who was convicted of burglarizing another store, an act that raised serious doubt as to his future trustworthiness. ${ }^{78}$ Some off-duty misconduct will interfere with supervisory authority in the plant. For example, an employee who assaulted the company's personnel manager at a local restaurant was properly fired because the attack on the supervisor could impair the manager's ability to carry out his supervisory functions in the future. ${ }^{79}$

An employee's conduct on or off duty may tarnish the company's reputation and jeopardize its goodwill. If so, the conduct may constitute just cause for discipline. For example, a bus driver was fired for engaging

76. Stowe-Woodward Co., 78 Lab. Arb. (BNA) 1038, 1044 (1982) (Thomson, Arb.); see also Zellerbach Paper Co., 68 Lab. Arb. (BNA) 69, 72 (1977) (Stashower, Arb.) (company obligatcd to employ handicapped worker only to the extent practicable).

77. Koppers Co., 77 Lab. Arb. (BNA) 708, 710 (1981) (Edes, Arb.); see also Weber Mfg., 63 Lab. Arb. (BNA) 56, 59 (1974) (Yaeger, Arb.). But see Hyco Inc., 66 Lab. Arb. (BNA) 86, 90 (1976) (Nichols, Arb.).

78. Safeway Stores, 74 Lab. Arb. (BNA) 1293, 1296 (1980) (Doyle, Arb.); see also New York Div. of Criminal Justice Servs., 79 Lab. Arb. (BNA) 65, 66-67 (1982) (Sabghir, Arb.) (conviction for selling methadone is just cause for dismissal).

79. Heaven Hill Distilleries, Inc., 74 Lab. Arb. (BNA) 42, 46 (1980) (Beckman, Arb.); see also Southwestern Ill. Coal Corp., 80 Lab. Arb. (BNA) 806, 808 (1983) (Hewitt, Arb.); Allied Aviation Serv., 60 Lab. Arb. (BNA) 441, 443 (1973) (Turkus, Arb.). 
in sexual acts with a young female passenger on his bus, which was parked on a public street in the middle of the day. His conduct certainly jeopardized the public image of the bus company. ${ }^{80}$ Nothing in the standard collective bargaining agreement requires the employer to tolerate an employee who does it more harm than good. In another bus company case, a driver was discharged for his well-pubhicized off-duty activities as the Grand Dragon of the Ku Klux Klan. The company faced the prospect of the serious economic loss that would result from a boycott threatened by the outraged local community if the driver was not fired. The arbitrator upheld the discharge because the driver's off-duty conduct prevented him from fulfilling his job responsibilities. The threatened loss to the employer justified the dismissal. ${ }^{81}$ In short, the driver's off-duty conduct directly interfered with the employer's successful operation of the enterprise.

Arbitrators should be extremely cautious when dealing with allegations of off-duty interference with the company's business. They must insist on a showing of actual or highly probable harm, and require management to prove that the disciplime imposed was proportionate to that harm. If the employer can supply the necessary proof, disciphine is appropriate for the employee's failure to fulfill his part of the employment bargain.

\section{B. Achievement of Legitimate Management Objectives.}

Illustration 5: Rehabilitation. An employer will disciphine an employee in order to further its interest in obtaining satisfactory work. One purpose of such discipline is to rehabilitate the employee and thus increase his productivity. An arbitrator must consider the rehabilitation objective when reviewing discipline under the just cause standard. As the following two cases illustrate, however, management must show that the degree of discipline was appropriate.

In the first case, a television station suspended a video tape editor for one day because he failed to review completely a tape that was tele-

80. Regional Transp. Dist., 80 Lab. Arb. (BNA) 1225, 1233-34 (1983) (Eaton, Arb.); see also Southern Bell Tel. \& Tel. Co., 75 Lab. Arb. (BNA) 409, 415-16 (1980) (Seibel, Arb.) (dismissal of a telephone company employee upheld where employee, while off duty and not on company property, made harassing and obscene calls that hurt company's business interest); NRM Corp., 51 Lab. Arb. (BNA) 177, 180-81 (1968) (Teple, Arb.) (dismissal upheld where employee had been charged with engaging in criminal activity while not on company's premises; employee could no longer be trusted).

81. Baltimore Transit Co., 47 Lab. Arb. (BNA) 62, 66-67 (1966) (Duff, Arb.); see also Trailways Southeastern Lines, 81 Lab. Arb. (BNA) 712, 716 (1983) (Gibson, Arb.) (dismissal held proper where bus driver clinically diagnosed as alcoholic engaged in felonious conduct that was reported in newspapers; his conduct damaged employer's reputation). 
vised. The tape contained blank frames and extraneous material, and it mismatched audio with video. The arbitrator ruled that management could discipline the employee in order to rehabilitate him, but the less severe penalty of a written reprimand would have been adequate to achieve this objective. ${ }^{82}$

In the second case, the arbitrator set aside the discharge of a mill operator who bored a guide bearing incorrectly. Although the employee had been verbally cautioned twice before, the company failed to consider whether the employee could have been rehabilitated. Since his work record indicated that rehabilitation was possible, the employee was reinstated. ${ }^{83}$

Illustration 6: Specific Deterrence. A second objective of discipline is to deter the employee from repeating unsatisfactory conduct. Arbitrators have routinely upheld discipline designed for specific deterrence. Thus, an employer properly suspended an employee who disregarded orders to stop readimg on the job and refused to perform a certain assignment. ${ }^{84}$ Another employer was allowed to discipline an employee who continued to produce work below reasonable production levels. ${ }^{85} \mathrm{~A}$ third employer properly suspended an employee for five days after he was discovered painting a friend's house on the day he called in sick. ${ }^{86}$

In each of these cases, discipline was intended to deter the employee from similar misconduct and was a reasonable means of achieving that objective. The reasonableness of discipline in these cases is important. If the discipline is not proportional to the offense or is substantially more severe than needed for deterrence, an arbitrator might reduce the discipline. ${ }^{87}$

Illustration 7: General Deterrence. In some situations, an employer may discipline an employee in order to set an example for other workers. Discipline, in other words, may be intended to show that the

82. Post-Newsweek Stations, 82 Lab. Arb. (BNA) 386, 389 (1984) (Daniel, Arb.).

83. Montague Mach. Co., 78 Lab. Arb. (BNA) 172, 176 (1982) (Bornstein, Arb.); see also Canron, Inc., 72 Lab. Arb. (BNA) 1310, 1312-13 (1979) (Marcus, Arb.) (dismissal was unfair and the employee was reinstated where employee received only general warnings, and violations were minor).

84. Library of Congress, 73 Lab. Arb. (BNA) 1092, 1100 (1979) (Aronin, Arb.); see also General Elec. Co., 72 Lab. Arb. (BNA) 405, 407-08 (1979) (Craver, Arb.).

85. Lash Distrib., Inc., 74 Lab. Arb. (BNA) 274, 278 (1980) (Darrow, Arb.); see also WallaceMurray Corp., 73 Lab. Arb. (BNA) 385, 387 (1979) (Seifer, Arb.); Crosby Group, 72 Lab. Arb. (BNA) 787, 788 (1979) (Davis, Arb.).

86. City of Appleton, 62 Lab. Arb. (BNA) 342, 345 (1974) (Lee, Arb.).

87. See, e.g., Boise Cascade Corp., 83 Lab. Arb. (BNA) 175, 179 (1984) (Gallagher, Arb.); City of Detroit, 82 Lab. Arb. (BNA) 1049, 1054-55 (1984) (Roumell, Arb.); Post-Newsweek Stations, 82 Lab. Arb. (BNA) 386, 389-90 (1984) (Daniel, Arb.). 
misconduct will not be tolerated. To achieve this objective, it may be necessary to dismiss an employee even if that employee is not likely to commit similar acts in the future. Some conduct is so serious that extreme measures may be used to discourage others from such activities.

In one such case, an employee struck his supervisor without provocation and threatened to "cut the throat" of the plant manager. Because the conduct, if repeated by other employees, would obviously hamper managers in carrying out their essential functions, the employee's discharge was upheld. ${ }^{88}$ The arbitrator noted that the harm caused by the employee "need not be measured in medical bills or blood."89 In a second case, an airport cleanmg service fired an employee who threatened to blow up an airplane. The arbitrator upheld the company's action on the ground that the company could not afford to condone such egregious conduct. 90

Illustration 8: Protection of the Ability to Operate a Business Successfully-Business Reputation. There are circumstances when an employer may discipline or discharge an employee in order to protect management's ability to operate the enterprise successfully and thereby enforce the employee's obligation to provide satisfactory work. ${ }^{91}$ A few further examples will suffice.

A bus company fired a driver who pled guilty to criminal charges of breaking and entering into his estranged wife's house with intent to commit murder. The arbitrator upheld the discharge, noting that the press coverage, which identified the driver as an employee of the bus company, clearly damaged the employer's business reputation. ${ }^{92}$ Proof of actual harm is essential. Thus, when an employer fired an employee for selling marijuana to an undercover agent, the arbitrator ruled that the discharge was unjustified because the company failed to prove that its reputation was injured by the incident. ${ }^{93}$ Although a company may discipline an

88. Heaven Hill Distilleries, Inc., 74 Lab. Arb. (BNA) 42, 46 (1980) (Beckman, Arb.); see also ITT Continental Baking Co., 75 Lab. Arb. (BNA) 764, 768-70 (1980) (Flagler, Arb.) (upholding discharge of employee who verbally abused supervisor and sprayed supervisor with high pressure water hose); Central Soya Co., 74 Lab. Arb. (BNA) 1084, 1090 (1980) (Cantor, Arb.) (upholding discharge of employee who threatened to kill foreman).

89. Heaven Hill Distilleries, Inc., 74 Lab. Arb. (BNA) 42, 46 (1980) (Beckman, Arb.).

90. Allied Aviation Serv., 77 Lab. Arb. (BNA) 455, 458 (1981) (Turkus, Arb.); see also Ralston Purina Co., 75 Lab. Arb. (BNA) 313, 321 (1980) (Brown, Arb.) (upholding firing of employee who phoned bomb threat).

91. See supra notes 78-81 and accompanying text.

92. Trailways Southeastern Lines, 81 Lab. Arb. (BNA) 712, 716 (1983) (Gibson, Arb.).

93. Vulcan Asphalt Ref. Co., 78 Lab. Arb. (BNA) 1311, 1313 (1982) (Welch, Arb.); see also Maust Transfer Co., 78 Lab. Arb. (BNA) 780, 783 (1982) (Lacugna, Arb.) (employee's off-duty dishonesty did not seriously injure employer). 
employee in order to protect its ability to operate its business successfully, it must establish that its business interests have been harmed by the employee's off-duty conduct.

\section{Assurance of "Fairness."}

Illustration 9: Industrial Due Process. Our theory of just cause recognizes that the union seeks to ensure fairness in disciplinary matters. The following examples illustrate one way a union seeks to guarantee fairness-by insisting on certain procedural prerequisites to discipline. These requirements form the concept of "industrial due process."

Management must adequately investigate an incident prior to deciding whether to discipline an employee. Failure to do so may taint the disciplinary decision. For example, when a company fired an einployee for stealing money from a supervisor's car after hearing only the supervisor's version of what occurred, an arbitrator held that failure to obtain the employee's version of the story violated basic notions of fairness and due process. Management cannot act first and only later determine whether the employee deserved the discipline. ${ }^{94}$

Due process also means that the discipline imposed inust be consonant with the wrongful conduct. In many situations, such as those involving absenteeism and poor work performance, manageinent must impose discipline in gradually increasing degrees. Sudden imposition of the maximum penalty is often unwarranted. In such a case, an arbitrator is likely to reduce the penalty. For example, an arbitrator ruled that management wrongly fired a crane operator for carelessly leaving a steel plate suspended. The employee had received no prior discipline that might have indicated a pattern of carelessness. Although the employee's act was certainly not blaineless, the arbitrator returned him to active duty, but without back pay. ${ }^{95}$

When management has tried several times to reinedy a problem with ininor discipline, a final decision to discharge the repeat offender can be quite reasonable. In such a case, a bus driver was fired for carelessly colliding with another vehicle owned by the bus company. Over a period of years, the employee had been involved in a series of preventable accidents for which he had been warned and suspended. The arbitrator

94. See American Bakeries Co., 77 Lab. Arb. (BNA) 530, 534 (1981) (Modjeska, Arb.); see also Associated Grocers of Colo., 82 Lab. Arb. (BNA) 414, 419-20 (1984) (Smith, Arb.).

95. Production Steel Co., 82 Lab. Arb. (BNA) 229, 232 (1984) (Roberts, Arb.); see also Canron, Inc., 72 Lab. Arb. (BNA) 1310, 1313 (1979) (Marcus, Arb.) (penalty reduced from discharge to one month suspension where employer failed to give employee clear and specific warning that he was producing unacceptable number of defective welds). 
upheld the discharge, stating that the company "extended its efforts at fairness, understanding, and assistance far beyond the point a reasonable mind might anticipate." 96

Illustration 10: Industrial Equal Protection. A union also has an interest in consistent application of discipline. Management must treat like cases alike. If the union can demonstrate that an employee was treated more harshly than similarly situated employees, the arbitrator will likely sustain the grievance.

In one case, an employer fired an employee for having beer on the company's premises in violation of a rule strictly prohibiting such conduct. The company had been lax in its enforcement of this rule and had excused other violations. Although finding the rule reasonable, the arbitrator sustained the grievance because it had not been consistently enforced. ${ }^{97}$ In another case, an employer dismissed an employee who had been progressively disciplined for poor attendance without noticeable improvement. The employee's final absence, the "last straw," was due to sickness. The union argued that the company had regularly accepted illness as a valid excuse for absence, but the evidence failed to support its claim. The arbitrator upheld the company's action. ${ }^{98} \mathrm{Had}$ the union been able to document its position, the discharge might well have been overturned. 99

Illustration 11: Individualized Treatment. The final way in which a union seeks fairness in discipline is by insisting on the consideration of mitigating factors. Normally in a discharge case the dismissed employee's entire work record will be examined. A long and satisfactory record may cause an arbitrator to reduce the level of discipline imposed. For example, in one case, a public utility fired an employee who had sexually harassed a fellow employee in violation of the employer's work rules. The arbitrator stressed the seriousness of the misconduct, but after considering the employee's twenty-eight year service record, he concluded that the discharge should be reduced to a seven-month suspen-

96. Metropolitan Atlanta Rapid Transit Auth., 80 Lab. Arb. (BNA) 829, 835 (1983) (Singer, Arb.).

97. Western Paper Box, 81 Lab. Arb. (BNA) 917, 921 (1983) (Concepcion, Arb.); see also Visador Co., 73 Lab. Arb. (BNA) 578, 579-80 (1979) (Seifer, Arb.); Shenango, Inc., 67 Lab. Arb. (BNA) 869, 870 (1976) (Cahn, Arb.).

98. Stokely Van Camp, Inc., 81 Lab. Arb. (BNA) 677, 680 (1983) (Schaffer, Arb.).

99. A bald claim of prior condonation of similar misconduct will not establish disparate treatment. The union must present proof that similar misconduct has been excused or treated more leniently. When such proof is presented, the discipline may not stand. See, e.g., Carnation Co., 3 LAB. REL. REP. (BNA) (84 Lab. Arb.) 80, 84 (Jan. 7, 1985) (Wright, Arb.); Shenango, Inc., 67 Lab. Arb. (BNA) 869, 869-70 (1976) (Cahn, Arb.). 
sion. ${ }^{100}$ In the usual case involving the discharge of an employee for fighting with a co-worker, "[m]any years of seniority alone will not save his job." 101 However, in a case where an employee involved in a fight had eighteen years seniority, a satisfactory work record, and, at age fiftyseven, no reasonable opportunity to obtain other employment in his town, an arbitrator ordered his reinstatement on six months probation, but without back pay. ${ }^{102}$

In absenteeism cases, unions will often try to explain the employee's attendance problems, introducing evidence of alcoholism, ${ }^{103}$ family illness, ${ }^{104}$ or a personal illness that has since been cured. ${ }^{105}$ Such facts may show that the employee's poor attendance record is not an accurate predictor of his ability or willingness to meet his attendance obligations in the future. A penalty less severe than discharge might then be warranted.

\section{CONCLUSION}

When the parties to a collective bargaining agreement adopt the standard of just cause, they expect that an arbitrator will apply the principle in the manner they intend. Unfortunately, the parties rarely explain their intentions in any detail. By examining the interests of the parties in a discipline case, an arbitrator can make sound judgments about the probable expectations of the parties. The common adherence of labor and management to general principles of fairness, efficiency, rehabilitation, and deterrence, indicates that both wish the disciplinary system to accomphish similar objectives.

This article has presented a systematic model of just cause, one that will guide the parties in their day-to-day activity and help an arbitrator resolve disciplinary grievances. Using the fundamental understanding of the employment relationship, as amended in the collective bargaining agreement, the model describes the components of the employee's obligation to provide satisfactory work and lists management's legitimate

100. Dayton Power \& Light Co., 80 Lab. Arb. (BNA) 19, 21-22 (1982) (Heinsz, Arb.); see also Capital Dist. Transp. Auth., 72 Lab. Arb. (BNA) 1313, 1318 (1979) (Cutler, Arb.) (reinstatement ordered in light of grievant's confused report concerning alleged sexual harassment and in light of employee's 17-year service record).

101. Kelly-Springfield Tire Co., 37 Lab. Arb. (BNA) 704, 706 (1961) (McCoy, Arb.).

102. R.J. Tower Corp., 68 Lab. Arb. (BNA) 1160, 1163-66 (1977) (Roumell, Arb.).

103. See Youngstown Hosp. Ass'n, 82 Lab. Arb. (BNA) 31, 33 (1983) (Miller, Arb.); Warner \& Swazey Co., 71 Lab. Arb. (BNA) 158, 158-59 (1978) (Seigel, Arb.).

104. See County of Monroe, 72 Lab. Arb. (BNA) 541, 543 (1979) (Markowitz, Arb.).

105. See Safeway Stores, 79 Lab. Arb. (BNA) 742, 746-48 (1982) (MacLean, Arb.); see also Union Camp Corp., 80 Lab. Arb. (BNA) 156, 158 (1982) (Coxe, Arb.); East Ohio Gas Co., 78 Lab. Arb. (BNA) 71, $72-73$ (1982) (Michelstetter, Arb.). 
objectives for imposing discipline. This theory of just cause also includes certain protections for employees that reflect the union's interest in guaranteeing fairness and accuracy in the application of discipline. Management objectives and union interests are coinpatible in most cases because both derive from the fundainental understanding.

This article's theory of just cause does not transform the arbitrator's function into that of a technician, fitting evidence into tabbed slots and reaching a mechanical solution. ${ }^{106}$ Inevitably, resolving a discipline case involves skilled judgment. The Supreme Court has cautioned that the arbitrator "does not sit to dispense his own brand of industrial justice," 107 but, as Professor Edgar Jones has perceptively argued, at the end of the grievance process there is only the arbitrator's sense of justice:

Yet any arbitrator who has looked down the long corridor of his conscience at a "just cause" disciplinary grievance is apt to feel that, at best, it is a pious sentiment, and, at worst, that it obscures and encumbers the abrasive necessity of pulling all the eleinents of decision, including whatever biases he may experience, down into plain view. The parties in the "just cause" provision have conferred upon management the discretion to disciplime the employees, but only for "just cause." Can it be said that the arbitrator does not sit to dispense his own brand of justice in that case? At that point, what other brand could there possibly be? ${ }^{108}$

The arbitrator's judgment can be guided by a conceptual model of just cause, a model of the sort proposed here. Every decisionmaker inust determine the facts of a case by, for example, resolving questions of credibility. Our model recognizes that the labor arbitrator must do more than that. He must decide whether the employee failed to provide satisfactory work; whether the discipline furthered one of management's legitimate interests; and whether the employer has provided industrial due process, industrial equal protection, and individualized treatinent. The value of a systematic model of just cause, in short, lies not in its ability to supply the right answers, but rather in its power to force the arbitrator to confront the right questions.

106. See Ritzenthaler Bus Lines, 82 Lab. Arb. (BNA) 543, 545 (1984) (Edes, Arb.) (“‘J]ust cause cannot be determined by any readily applied mechanical rule.").

107. United Steelworkers v. Enterprise Wheel \& Car Corp., 363 U.S. 593, 597 (1960).

108. Jones, Power and Prudence in the Arbitration of Labor Disputes: A Venture in Some Hypotheses, 11 UCLA L. REV. 675, 764 (1964). 